\title{
Physicochemical properties of native and extruded maize flours in the presence of animal proteins.
}

Ángela Bravo-Núñez*, Manuel Gómez

Food Technology Area. College of Agricultural Engineering. University of Valladolid, 34071 Palencia, Spain.

*Corresponding author e-mail: angela.bravo.nunez@gmail.com

\begin{abstract}
Interest for protein-enriched starchy products has increased, as protein intake moderately higher than current recommendations may provide health benefits for ageing populations. Influence of the substitution of native or extruded flours by $25 \%$ or $50 \%$ of proteins (collagen, milk, whey or egg white proteins) was studied. Collagen was the only protein that increased water binding capacity ( $\mathrm{p}<0.05$ ) up to $233,72 \%$ for mixtures with native and up to $40.85 \%$ for mixtures with extruded flours. Regarding gelling properties, regardless used flour, mixtures with 50\% of collagen increased water absorption index and swelling power $(\mathrm{p}<0.05)$ by $\sim 100 \%$, while mixtures with $50 \%$ of egg white protein decreased water absorption index by $\sim 40 \%$ ( $<<0.05)$. Pasting viscosity decreased in flour-protein mixtures, except the ones with egg white protein, that increased. Endotherm peaks shifted to higher temperatures when proteins were present. Regarding viscoelastic behaviour, when using native flour and higher protein content, gels presented stronger gel behaviour.
\end{abstract}

Keywords: Maize flour; pregelatinisation; proteins; dairy; collagen; egg white. 


\section{Introduction}

Functional food products have been defined as foods that provide an added health benefit over and above the food product's traditional nutritional value [1]. In this manner, interest for protein-enriched starchy products has increased by both the food industry and consumers during recent years. A protein intake moderately higher than current recommendations may provide health benefits for ageing populations [2]. There is also convincing evidence stating that diets with higher protein content increase thermogenesis and satiety compared to diets with lower protein content [3], and therefore the substitution of starch, main carbohydrate in cereals, by proteins in weight-loss diets could be interesting in weight-loss diets. Animal proteins, such as dairy, egg and meat proteins, seem to be more digestible than vegetal proteins [4]. In addition to digestibility, amino acids from animal proteins are not as likely to be converted to urea as amino acids from vegetal proteins [5]. Although vegetal proteins have also their benefits, it seems clear that proteins coming from animal sources are more efficiently utilized within the body.

Besides the nutritional aspects, there has been continued research interest in polysaccharideprotein systems because they can function as gelling agents, thickeners, emulsifiers, texture modifiers or stabilizers in foods [6]. The underpinning reason for this research resides in the influence that proteins have in the behaviour of flours. When elaborating starchy products, hydration, pasting, thermal, rheological and gelling properties of flours are important parameters that will influence the behaviour of flours when applying to products. Sometimes these properties are not optimal in native starch, and thus need to be modified by various techniques to better suit the relevant end product [7]. Extrusion is one of these such techniques, as this process not only modifies native starch to achieve changes in the technological behaviour, but also gives clean label products, which is something that many consumers are notably concerned about presently.

Many researchers have reported on the interactions between native flours/starches with animal proteins. Regarding dairy proteins, several authors focused on interactions of different starches with casein proteins [8-12], while others focused on starch interactions with whey proteins [1317]. In each research study, the percentage of protein used was different, ranging from $0.5 \%$ to $75 \%$, making it difficult to draw comparisons between the results from each. To a lesser extent, other animal proteins like egg or collagen have also been studied. Regarding egg protein, its effect on the interfacial properties and foaming capacity of rice starches [18], or the effect of this 
protein on the solution and emulsion properties of barley starches [19] were studied, including in both studies chemically modified starches. For collagen, its effect on the mechanical properties of corn starch films have been investigated [20].

Regarding interactions between pregelatinised flour/ starch and animal proteins, only one article was found, and it focused on the interaction with whey protein [21], although the pregelatinised flours where not obtained by extrusion process.

Despite the multiple available reports of the effect of animal proteins on the behaviour of flours /starches, limited information is available for comparing the effect of different animal proteins on the same flours/starches, since experimental conditions and protein percentages are not always the same. Therefore, comparing several proteins simultaneously will guarantee these parameters to be the same, which will help to make reliable comparisons regarding the interactions of different proteins with flours.

The aim of the present work was to analyse the influence of different animal proteins (egg white, whey, milk and collagen proteins) on the properties of two maize flours (native and extruded). Interactions between native and extruded maize flours and different animal proteins (collagen, milk, whey and egg white) were studied by substitution of 25 and $50 \%$ of the flour. Flourprotein mixtures were prepared by substitution of 25 and $50 \%$ of the flour by commercial proteins powders. The mixtures were dry-blended before analysis. Hydration, pasting, thermal and gelling properties of all the mixtures and controls were studied.

\section{Materials and methods}

Native (NMF) (moisture and protein content of $11.05 \mathrm{~g} / 100 \mathrm{~g}$ and $7.6 \mathrm{~g} / 100 \mathrm{~g}$, respectively) and extruded (EMF) maize flours were provided by Molendum Ingredients (Zamora, Spain). The extrusion treatment was performed with an industrial Bühler Basf single screw extruder (Bühler S.A., Uzil, Switzerland). The length to diameter (L/D) ratio for the extruder was 20:1. The extrusion was carried out with a further water addition of $12 \%$ at a maximum barrel temperature of $60{ }^{\circ} \mathrm{C}$, a feed rate of $500 \mathrm{~kg} / \mathrm{h}$ and a screw speed of $453 \mathrm{rpm}$. The extruded product was dried by convection air until $10.09 \%$ moisture and then ground with a compression roller to a particle size bellow $200 \mu \mathrm{m}$. Extrusion parameters where chosen by the company based on previous research in order to obtain complete gelatinization of the starch with minimum dextrinization. Animal proteins of milk (mixture of native micellar casein and whey proteins ) ( $\geq 85 \%$ protein) 
(Solmilko MPI, Glanbia, Ballyragget, Ireland), whey ( $\geq 88 \%$ protein) (Provolon 295, Glanbia, Ballyragget, Ireland), collagen ( $\geq 94 \%$ protein) (Scanpro T95, BHJ Protein Foods, Gråsten, Denmark) and egg white ( $\geq 80 \%$ protein) (Egg white powder Specialist, Occhiobello, Italy), with solubility's of $0.33,0.54,0.03$ and $1.00 \mathrm{mg}$ soluble protein/ $\mathrm{mg}$ total protein respectively, measured with the Quick Start ${ }^{\mathrm{TM}}$ Bradford Protein Assay (Bio Rad, Hercules, California, United States), were used for the flour-protein mixtures.

\subsection{Hydration and gelling properties}

Hydration properties were analysed following the methodology of Martínez et al. [22] with modifications. Swelling volume (SV), or the volume occupied by a known weight of sample after hydration with water over time, was evaluated by adding $100 \mathrm{~mL}$ of distilled water to $5 \mathrm{~g}$ $( \pm 0.1 \mathrm{~g})$ of sample and allowing it to hydrate for $20 \mathrm{~h}$ at $25^{\circ} \mathrm{C}$, values were expressed as volume (mL) per gram of solid. Water holding capacity (WHC), defined as the amount of water retained by the sample without being subjected to any stress, was determined on the same suspension used to evaluate SV; the hydrated solid was weighed after removing the excess of water and values were expressed as grams of water per gram of solid. Water binding capacity (WBC), or the amount of water retained by the sample after it has been centrifuged, was determined by adding $25 \mathrm{~g}$ of distilled water to $1.25 \mathrm{~g}( \pm 0.1 \mathrm{~g})$ of sample, mixing it vigorously and centrifuging at $580 \mathrm{x} g$ for $10 \mathrm{~min}$. The resulting hydrated solid was weighed after removing the excess of water, and results were expressed as grams of retained water per gram of dry sample. Hydration properties were analysed in duplicate form different mixtures batches.

Regarding gelling properties, water absorption index (WAI), swelling power (SP) and water solubility index (WSI) were determined following the method of Toyokawa et al. [23], with the modifications of Rosell et al. [24]. Samples (50 $1 \mathrm{mg}$ ) (Wi) were dispersed in $1 \mathrm{~mL}$ of distilled water in a 1,5 mL Eppendorf tube with a rod, and heated at $90{ }^{\circ} \mathrm{C}$ for $10 \mathrm{~min}$ in a water bath. Samples were then cooled down in a water bath with ice for $10 \mathrm{~min}$. Subsequently, samples were centrifuged at $3000 \times \mathrm{g}$ at $4{ }^{\circ} \mathrm{C}$ for $10 \mathrm{~min}$. Supernatants were decanted in evaporating plates and the remaining residue in the 1,5 mL Eppendorf was weighed $(\mathrm{Wr})$. Supernatants were allowed to dry at $105{ }^{\circ} \mathrm{C}$ for $24 \mathrm{~h}$. Dry solids were weighed (Ws). WAI, SP and WSI were calculated as follows:

$$
W A I\left(\frac{g}{g}\right)=\frac{W r}{W i}
$$




$$
\begin{gathered}
W S I\left(\frac{g}{100 g}\right)=\frac{W S}{W i} * 100 \\
S P\left(\frac{g}{g}\right)=\frac{W r}{W i-W s}
\end{gathered}
$$

Gelling properties were analysed in duplicate form different mixtures batches.

\section{2 Pasting properties}

Pasting properties of the samples were analysed using a Rapid Visco Analyser (Model RVA-4C, Newport Scientific Pty. Ltd., Warriewood, Australia). $3.5 \mathrm{~g} \mathrm{(} \pm 0.1 \mathrm{~g})$ of sample (dry basis) was dispersed in $25 \mathrm{~g}( \pm 0.1 \mathrm{~g})$ of distilled water. The obtained slurries were then subjected to heating and cooling cycles programmed to follow the general AACC pasting method [25].

All measurements were performed in duplicate.

\section{3 Differential scanning calorimetry (DSC)}

Thermal properties of samples were analysed using a Q-20 differential scanning calorimeter (TA instruments, Crawley, UK) equipped with a refrigerated cooling system RCS40 (TA instruments, Crawley, UK). An empty pan and dry nitrogen at a flow rate of $50 \mathrm{~mL} / \mathrm{min}$ as the purge gas were used as a reference. A weight of $3.0 \mathrm{mg}$ sample (dry basis) together with distilled water $(1: 2 \mathrm{w} / \mathrm{w})$ were placed in an aluminium pan (T140613) covered with a hermetic lid (T140804). To avoid moisture loss, pans were sealed hermetically and stored for $24 \mathrm{~h}$ at $4{ }^{\circ} \mathrm{C}$ before experimentation to allow for complete hydration of samples. All samples were maintained isothermally at $20^{\circ} \mathrm{C}$ for $2 \mathrm{~min}$ before being heated from 20 to $98^{\circ} \mathrm{C}$ at $10^{\circ} \mathrm{C} / \mathrm{min}$. Onset temperature (To), peak temperature (Tp), conclusion temperature (Tc) and enthalpy (J/g) of starch gelatinization were determined. All experiments were performed in duplicate from different mixtures batches.

\section{4 Rheological measurements}

Samples for dynamic viscoelastic properties were prepared using RVA AACC pasting method [25]. However, the final temperature of the RVA test was set at $30^{\circ} \mathrm{C}$ instead of $50{ }^{\circ} \mathrm{C}$. The time between the end of the RVA analysis and the placement of the samples in the rheometer was of 1 min.

Rheological measurements were performed using a rheometer (Haake RheoStress 1, Thermo Fischer Scientific, Scheverte, Germany) equipped with a titanium parallel serrated plate geometry sensor PP60 Ti (60 mm diameter) and $1 \mathrm{~mm}$ gap. The sample was placed into the rheometer and stabilized at $30{ }^{\circ} \mathrm{C}$ with a Phoenix II P1-C25P water bath (Thermo Fisher 
Scientific, Schwerte, Germany). To avoid sample drying, space between the plates was covered with Panreac vaseline oil (Panreac Química S.A., Castellar del Vallés, Spain). The pastes rested for $500 \mathrm{~s}$ before the test was started. Two dynamic viscoelastic measurements were made: (1) deformation sweeps at a constant frequency $(1 \mathrm{~Hz})$ to determine the maximum deformation attainable by a sample in the linear viscoelastic range, and (2) frequency sweeps over a range of $0.01-100 \mathrm{~Hz}$ at a constant deformation within the linear viscoelastic range. For each measurement a fresh sample was used in order to avoid different waiting times that could influence the behaviour of the samples. The storage modulus $\left(G^{\prime}\right)$, loss modulus $\left(G^{\prime \prime}\right)$ and loss factor ( $\tan \delta=G^{\prime \prime} / G^{\prime}$ ) as a function of frequency $(\omega)$ were obtained. All measurements were made in duplicate from different batches.

\subsection{Statistical analysis}

To study the differences between the characteristics of the mixtures according to the percentage and type of both flour and protein analysis of variance (ANOVA) was used. Fisher's least significant difference (LSD) test was used to describe means with $95 \%$ confidence. The analysis was performed using Statgraphics Centurion XVII software (Statpoint Technologies, Warrenton, USA).

\section{Results and Discussion}

\subsection{Hydration properties}

Hydration properties (WHC, WBC and SV) are shown in Table 1. When using native flour, only mixtures with collagen enhanced all hydration properties significantly ( $<<0.05), 62.55 / 73.13 \%$, $84.30 / 233.72 \%$ and $73.33 / 100 \%$ higher (depending if protein percentage was $25 \%$ or $50 \%$ ) for WHC, WBC and SV respectively. Mixtures with milk proteins enhanced significantly $(\mathrm{p}<0.05)$ values of WBC (50\% for the highest protein percentage) and SV (53.33 and $66.67 \%$ for 25 and $50 \%$ of protein). Significant differences between percentages for these two proteins were only observed for WBC $(81.07 \%$ and $37.23 \%$ higher for mixtures collagen and milk proteins respectively when protein content was $50 \%$ ). For mixtures with egg white or whey proteins, a decrease in WHC and WBC was observed when increasing protein content, although significant differences $(\mathrm{p}<0.05)$ were only observed for the highest protein percentage. WHC and WBC were reduced 41.85 and $70.50 \%$ by the presence of egg protein, while the presence of whey protein resulted in reductions of 51.54 and $75.81 \%$. No significant differences with respect to 
the control were found for SV. These differences can be due to the hydration properties of the proteins alone, since collagen and milk are the ones that presented the higher hydration properties (WHC 177.97 and 172.25 \% higher than normal flour), while egg white presented a relatively low values ( WHC $45.37 \%$ lower) and whey protein was not able to retain water.

Protein solubility (shown in materials and methods) seems to be related with hydration properties, since these values follow an inversely proportional relationship with protein solubility. In agreement with this, Shin, et al. [26] observed that other more soluble proteins reduced values of $\mathrm{WBC}$ of rice flours.

The fact that collagen protein presented the highest hydration properties, alone and when in mixtures, can be explained on the basis of how collagen interacts with water. A collagen fibril can be described as crystalline due to its regular arrangement of identical subunits in the axial direction and semi-crystalline in the lateral direction corresponding to disorder in the packing arrangement of the collagen fibrils [27]. When interacting with water, the water molecules organize in a semi-clathrate-like structure that surrounds and interconnects triple helices in the crystal lattice, where hydroxyprolyl groups play a crucial role in the assembly [28]. This tight interaction of water with collagen may be responsible for the increase in the hydration properties of this protein. The hydration properties were also augmented when using milk protein (composed of native micellar casein and whey proteins), which may be due to the limited solubility of casein proteins, since a drop in solubility of starch-sodium caseinate systems when compared to a native starch was reported by Doublier et al. [9].

When using egg white or whey protein, the reduction of the hydration properties may be due to the amino acid composition of the protein. Amino acid residues with charged groups bind about $6 \mathrm{~mol} \mathrm{water} / \mathrm{mol}$ residue, the uncharged polar residues bind about $2 \mathrm{~mol} / \mathrm{mol} \mathrm{residue}$, and the nonpolar groups bind about $1 \mathrm{~mol} / \mathrm{mol}$ residue [29]. The hydration capacity of a protein therefore is related, in part, to its amino acid composition, as the greater the number of charged residues, the greater the hydration capacity. Kuntz \& Kauzmann, [30] confirmed this theory, since they reported that both ovoalbumin, the main protein of egg white proteins, and $\beta$ lactoglobulin, the main protein of whey proteins, had hydration capacities of 0.30 and $0.45 \mathrm{~g}$ water/g protein, respectively. Their values were much lower than our results for maize flour, and together with the significantly lower hydration values of our egg and whey protein respect 
the native maize flour, could justify the observed decrease in our mixtures containing these two proteins.

When using extruded flour, only collagen protein increased significantly $(\mathrm{p}<0.05)$ WHC, WBC and SV by $10.27 / 16.03,14.47 / 40.85$ and $27.71 / 45.78 \%$ respectively, depending if protein percentage was 25 or $50 \%$. Significant differences between percentages were only found for WBC and SV.. Milk protein reduced significantly $(\mathrm{p}<0.05)$ WHC and SV by 24.81/31.04 and $16.87 / 18.08 \%$ (depending if protein percentage was $25 \%$ or $50 \%$ ). WBC was only significantly $(\mathrm{p}<0.05)$ reduced by milk protein when protein level was $50 \%$, by $8.51 \%$. Egg protein reduced WHC 37.79 and $67.18 \%$ when protein level was 25 or $50 \%$. For mixtures with whey protein, these reductions were 46.18 and $57.25 \%$. For WBC and SV, mixtures with egg or whey proteins behave similarly. When protein content was $25 \% \mathrm{WBC}$ was reduced $25.35 \%$, and $\sim 57 \%$ when protein content was $50 \%$. SV was reduced between 35 and $50 \%$.

The differences observed between mixtures with native flour and extruded flour may be due to the high hydration properties values that extruded flour presents due to its higher levels of gelatinized starch [31]. Since extruded flour presented higher hydration values than native flours, it seems logical to think that when substituting this flour with protein, even though protein will also contribute to the hydration properties, they would be reduced overall. The fact that collagen was the sole protein that increased hydration properties when mixing with both native and extruded flour confirm the theory that proteins also do contribute to hydration properties.

Gelling properties (WAI, WSI and SP) are shown in Table 2. For WAI and SP no significant differences $(p>0.05)$ were observed between native or extruded flours. Differences with hydration properties are attributable to the fact that, for assessing gelling properties, mixtures underwent a heat-moisture treatment that affected the functionality of native flour, since inner starch underwent a gelatinizing process. As starch is already gelatinized in extruded flours, in this case it is normal that no significant differences were found. In addition, no significant differences were found between the analogue mixtures with proteins, although WAI values were much higher than WHC values. This is because with the heat treatment proteins denaturize, modifying their capacity to retain water. For WAI and SP, only collagen mixtures with 50\% protein presented higher values of both WAI (103.09-111.90 \% higher) and SP (95.69-99.71\% higher) in comparison with both native and extruded flours. On the contrary, egg white protein 
mixture with $50 \%$ of protein presented a lower WAI value (43.42\% lower) with respect the extruded flour. These differences may be related with the capacity of the proteins to retain water after the thermal treatment, being higher for collagen and lower for egg white protein. The mixtures with the other proteins did not present significant differences with the controls, regardless of the protein percentage in the mixtures.

Regarding WSI, which measures the solubility of the mixtures, values extruded flour were $298.11 \%$ higher than values for native flour, although no significant differences were found, probably due to the high WSI of whey and egg proteins alone. Nevertheless, this difference between flours affected the WSI values of protein-flour mixtures, were it was observed that mixtures with extruded flour presented higher WSI values than the analogue mixtures with native flour. These results are in agreement with Hagenimana et al. [32]. These authors explained these differences by the dextrinization of starch during the extrusion process. Egg white proteinenhanced WSI values for both native and extruded flours, 927.67 and $1950.94 \%$ with native flour (depending in protein percentage), and 363.67 and $635.07 \%$ when mixtures were made with extruded flour. Milk and whey protein enhanced WSI for mixtures with $50 \%$ of protein. Respect native flour, this increase was 657,86 and $1276.10 \%$ for milk and whey proteins respectively; while for mixtures with extruded flour was 233.33 and $441.70 \%$. On the contrary, collagen did not modify WSI values of the flours, with the exception of the mixture of collagen with extruded flour at $50 \%$ of substitution, in which case WSI was reduced to 0 .

It can be said that behaviour of collagen protein-flours mixtures provided strong evidence for the high affinity that collagen proteins have with water and their ability to become integrated within the gel matrix, while behaviour of egg white protein-flours mixtures showed the opposite. It was also observed that the results obtained for the protein-flour mixtures are in agreement with the given solubility of proteins.

\subsection{Pasting properties}

Pasting properties of the mixtures and flours are shown in Figure 1. Native flour presented the typical behaviour of this type of flour with a sudden increase in the viscosity of the paste at temperatures above $70^{\circ} \mathrm{C}$ corresponding to starch gelatinisation. Meanwhile, extruded flour showed a higher initial viscosity with no heating, due to its ability of gelatinizing in cold water due to the high levels of gelatinised starch [31], followed by a decrease in viscosity as temperature increased, and a final slight increase in viscosity during the cooling stage. Overall 
viscosity of extruded flour was much lower than that of native flour, which is related to the extrusion process that this kind of flours undergo, as it might make the amylose chains lose the ability to retrograde during cooling due to their fragmentation during extrusion [31].

When using native flour, the incorporation of proteins increased the pasting temperature of the mixtures, with a more noticeable effect at higher protein levels. This increase is probably related to the water retention capacity of the samples and to competition phenomenon for available water, as reported by Eliasson [33], who studied the behaviour of wheat starch-gluten protein mixtures. Noisuwan et al. [34] reported that proteins adsorb onto starch granules, and this adsorption would restrict the diffusion of water into the starch granule during pasting, which could affect both pasting temperature and viscosity. For mixtures with native flour, the incorporation of dairy proteins (whey and milk proteins) and collagen decreased viscosity of the RVA curve after gelatinization, while egg white protein had the inverse effect. In all the cases the effect was higher with higher protein content of the mixture. It is known that egg white protein coagulates with a rise in temperature [35], which increases its viscosity [36, 37]; this is a probable reason for the higher viscosity of mixtures with this type of protein than that of the control. For the other proteins, the decrease in overall viscosity is likely due to the reduction in total starch, which is mainly responsible for the increase in viscosity during the gelatinization process. The observed viscosity reduction with mixtures of whey protein is in agreement with the observations of Noisuwan et al. [14] with rice starch and Onwulata et al. [15] with several starches. Regarding casein, a principal component of milk protein, the majority of investigations have observed an increase in the viscosity of the RVA curve with its incorporation $[9,11,12]$. Nevertheless, in these investigations protein was added and not used as a substitution for starch/flour, and therefore the dilution effect of starch was not an existing factor. In fact, Goel et al. [10] observed that while the addition of casein increased viscosity, the substitution of starch by protein had a reduction effect, which is in concordance with our results for milk protein.

When using extruded flour similar trends were observed, although overall viscosity was significantly lower in all the cases. It is important to note the fact that mixtures made with egg white protein showed a clear rise in viscosity respect the extruded flour during heating, which again can be attributed to protein coagulation [35-37]. However, the viscosity increase observed with extruded flour is much lower than that of native ones. This difference may be related to 
interaction phenomena between native and egg white protein, or to water competition between the two polymers in the case of extruded flours, with high WHC and WBC.

\subsection{Thermal properties}

Calorimetric results are shown in Table 3. Mixtures with extruded flours are not shown since these flour did not exhibit a gelatinization peak, which indicates that complete gelatinization of starch was achieved during the previous extrusion process [38]. For native flour mixtures, an enthalpy decrease was observed with the incorporation of proteins. This decrease was more pronounced for mixtures containing collagen, decreasing $23.09 \%$ when protein content was 25 $\%$ and $62.01 \%$ when protein content was $50 \%$. For the rest of the proteins a significant reduction was only observed when protein content was 50\%, being 14.34, 50.47 and $20.67 \%$ for egg white, milk and whey proteins respectively. These differences between gelatinization enthalpies (energy needed to dissociate amylopectin double helixes) may be due to the interaction between proteins and amorphous regions of starch granules [39] and water competition between polymers [33]. In fact, differences between mixtures containing collagen and the mixtures with the other proteins may be triggered by the higher hydration properties of this protein, which reduces the available water to a greater extent. Furthermore, decreasing available water for starch shifts endotherm peaks to higher temperatures [40]. Focusing on the endotherm peaks, it was observed that the endotherm shifted to higher temperatures as protein percentage increased, confirming the observations of the pasting properties. This effect is in accordance with observations from other studies of the interactions between starches and soy proteins [41, 42]. In our case this effect was more pronounced for egg white proteins. As reported before, this shift is associated with a competition between protein and starch polymers for water during the gelatinization stage [33]. In our case, differences between proteins cannot only be related with competition phenomena for water, since mixtures with egg white proteins were the ones that presented lower hydration values but experienced the greatest shift in the endotherm peak to higher temperatures (at least $2{ }^{\circ} \mathrm{C}$ more than when the other proteins where present for all To, Tp and Tc). The shift with egg white protein could be driven by the fact that at this temperature range both phenomena of starch gelatinization and egg white protein coagulation overlap [35]. It is interesting to note the temperature range where collagen protein gives an enthalpy peak, as no peak was observed in this range for the flour-collagen protein mixture. Explanation to this may be due to protein-flour interaction, but remains unclear. 


\subsection{Viscoelastic behaviour}

Mechanical spectra of the flour-protein mixtures obtained from the slurries after an RVA cycle are plotted in Figures 2 and 3. For native flour it was observed that $\mathrm{G}^{\prime}$ values were strongly dependent on the frequency at higher protein contents, while $G^{\prime \prime}$ were somewhat more independent but followed the same tendency. Some authors $[43,44]$ reported that when $\mathrm{G}^{\prime}$ is independent of the frequency and $\mathrm{G}^{\prime \prime}$ is somewhat dependent, a weak-gel behaviour results. For extruded flour, the pastes presented weaker behaviour than the ones with native flour. Loss factor increased in all the mixtures as frequency increased, and this increase was more pronounced when using extruded flour. Therefore, both presence of proteins and extruded flour had a negative effect in gels elasticity.

When using native flour, the incorporation of collagen and milk proteins did not modify G" values but did decrease G' values, with this effect being more evident at higher protein levels. Egg white and whey protein did not modify G" and only slightly reduced G' values for protein levels of $25 \%$. Meanwhile, for levels of $50 \%$ of protein both values increased with respect to the control, being more noticeable for mixtures with whey protein. Yang et al. [17] also reported that whey protein weakened the gel structure of the starch-protein mixtures at low protein content (0.3:1, 0.2:1 and 0.15:1 protein-starch ratios). These authors also observed that this decrease was more pronounced for lower protein levels, which could explain our results at high protein content. For its part, the increase of both $\mathrm{G}^{\prime}$ and $\mathrm{G}^{\prime \prime}$ at high egg white protein levels is probably related to heat aggregation of proteins [36].

When using extruded flour, mixtures presented lower $\mathrm{G}^{\prime}$ values and similar $\mathrm{G}^{\prime \prime}$ compared to the control as protein content increased, with the exception of the mixture with egg white protein at $50 \%$ protein level, that showed similar $\mathrm{G}^{\prime}$ and higher $\mathrm{G}^{\prime \prime}$, again probably due to heat aggregation of proteins [36]. Although rheology was measured from the obtained pastes after an RVA cycle, no correlations were found between final viscosity values of RVA and rheological values. RVA curves showed that the presence of egg white protein increased final viscosity regardless type of flour or protein percentage, while the presence of whey protein decreased final viscosity for both protein levels. Internal gel structure depends on the interactions between proteins and gelatinized starch, which can be developed during gelatinization or subsequently. 


\section{Conclusion}

The type and quantity of protein noticeably affects protein-flour interactions. Collagen protein was the only protein that enhanced hydration properties of both native and extruded flour (WHC was increased by $73.13 \%$ for mixtures with $50 \%$ of protein when flour was unmodified, and by $16.03 \%$ for this same percentage when flour was extruded). Milk protein increased WBC and SV when mixtures where made with native flour, while a decrease was observed when extruded flour was used. Egg and whey proteins reduced hydration properties when mixing with both native or extruded flours. Regarding gelling properties, for WAI and SP no significant differences were found between flours nor between analogue mixtures made with one flour or another. Only collagen mixtures with $50 \%$ protein presented higher values of both WAI $(\sim 105$ $\%$ higher) and SP ( $\sim 97 \%$ higher) than either of the flours. On the contrary, egg white protein mixture with $50 \%$ of protein presented a lower WAI value (43.42\% lower) with respect the extruded flour. Regarding WSI, higher values were found for mixtures made with extruded flour than for mixtures made with native flour, most probably because dextrinization of the extruded flour. Pasting properties decreased by the presence of collagen, whey and milk proteins, while egg white protein increased them and also changed the curve-shape for the extruded flour. Endotherm peaks of all mixtures shifted to higher temperatures because of water competition phenomena between polymers and denaturation of proteins, being this shift more evident when mixtures were made with egg protein than when made with the other proteins $\left(2^{\circ} \mathrm{C}\right.$ or more). In general terms, it can be stated that behaviour of protein-flour mixtures will affect physical properties of the doughs and batters and final quality of the protein-enriched product. This research can be useful for further development of bakery products with high protein content.

\section{Acknowledgements}

The authors acknowledge the financial support of the Spanish Ministry of Economy and Competitiveness (Project AGL2014-52928-C2-2-R) and the European Regional Development Fund.

\section{References}

[1] Frewer, L.; Scholderer, J.; Lambert, N. Consumer acceptance of functional foods: issues for the future. British Food Journal. 2003, 105, 714-731. 
[2] Nowson, C.; O’Connell S. Protein requirements and recommendations for older people: A review. Nutrients. 2015, 7, 6874-6899.

[3] Halton, T.L.; Hu, F.B. The effects of high protein diets on thermogenesis, satiety and weight loss: A critical review. Journal of the American College of Nutrition. 2004, 23, 3733-85.

[4] FAO. Report of a sub-committee of the 2011 FAO Consultation on "Protein Quality Evaluation in Human Nutrition"': the assessment of amino acid digestibility in foods for humans and including a collation of published ideal amino acid digestibility data for human foods. Rome (Italy): FAO; 2012.

[5] Bos, C.; Metges, C.C.; Gaudichon, C.; Petzke, K.J.; Pueyo, M.E.; Morens, C.; Everwand, J.; Benamouzig, R.; Tomé, D. Postprandial kinetics of dietary amino acids are the main determinant of their metabolism after soy or milk protein ingestion in humans. The Journal of Nutrition. 2003, 133,1308-15.

[6] Nishinari, K.; Zhang, H.; Ikeda, S. Hydrocolloid gels of polysaccharides and proteins. Current Opinion in Colloid and Interface Science. 2000, 5, 195-201

[7] Gunaratne, A.; Ranaweera, S.; Corke, H. Thermal, pasting, and gelling properties of wheat and potato starches in the presence of sucrose, glucose, glycerol, and hydroxypropyl $\beta$ cyclodextrin. Carbohydrate Polymers. 2007, 70, 112-122.

[8] Bertolini, A.C.; Creamer, L.K.; Eppink, M.; Boland, M. Some rheological properties of sodium caseinate-starch gels. Journal of Agricultural and Food Chemistry. 2005 53, 2248-2254.

[9] Doublier, J.L.; Marzin, C.; Visdeloup, S.; Lefebvre, J. Effect of sodium caseinate on the pasting behaviour of starches from different origins. Carbohydrate Polymers. 1994, 25, 228-229. [10] Goel, P.K.; Singhal, R.S.; Kulkarni, P.R. Studies on interactions of corn starch with casein and casein hydrolysates. Food Chemistry. 1999, 64, 383-389.

[11] Kett, A.P.; Chaurin, V.; Fitzsimons, S.M.; Morris, E. R.; O'Mahony, J.A.; Fenelon, M.A. Influence of milk proteins on the pasting behaviour and microstructural characteristics of waxy maize starch. Food Hydrocolloids. 2013, 30, 661-671.

[12] Lelievre, J.; Husbands, J. Effects of sodium caseinate on the rheological properties of starch pastes. Starch-Stärke. 1989, 41, 236-238.

[13] Dang, H.V.; Loisel, C.; Desrumaux, A.; Doublier, J.L. Rheology and microstructure of cross-linked waxy maize starch/whey protein suspensions. Food Hydrocolloids. 2009, 23, 16781686. 
[14] Noisuwan, A.; Bronlund, J.; Wilkinson, B.; \& Hemar, Y. Effect of milk protein products on the rheological and thermal (DSC) properties of normal rice starch and waxy rice starch. Food Hydrocolloids. 2008, 22, 174-183.

[15] Onwulata, C.I.; Tunick, M.H.; Thomas-Gahring, A.E. Pasting and extrusion properties of mixed carbohydrate and whey protein isolate matrices. Journal of Food Processing and Preservation. 2014, 38, 1577-1591.

[16] Sarabhai, S.; Prabhasankar, P. Influence of whey protein concentrate and potato starch on rheological properties and baking performance of Indian water chestnut flour based gluten free cookie dough. LWT-Food Science and Technology. 2015, 63, 1301-1308.

[17] Yang, H.; Irudayaraj, J.; Otgonchimeg, S.; Walsh, M. Rheological study of starch and dairy ingredient-based food systems. Food Chemistry. 2004, 86, 571-578.

[18] Asghari, A.K.; Norton, I.; Mills, T.; Sadd, P.; Spyropoulos, F. Interfacial and foaming characterisation of mixed protein-starch particle systems for food-foam applications. Food Hydrocolloids. 2016, 53, 311-319.

[19] Magnusson, E.; Nilsson, L. Interactions between hydrophobically modified starch and egg white yolk proteins in solution and emulsions. Food Hydrocolloids. 2011, 25, 764-772.

[20] Wang, K.; Wang, W.; Ye, R.; Liu, A.; Xiao, J.; Liu, Y.; Zhao, Y. Mechanical properties and solubility in water of corn starch-collagen composite films: Effect of starch type and concentrations. Food Chemistry. 2017, 216, 209-216.

[21] Shim, J.; Mulvaney, S.J. Effects of pregelatinization conditions and added whey protein isolate on corn starch dough properties. Cereal Foods World. 2002, 47, 440.

[22] Martínez, M.M.; Macias, A.K.; Belorio, M.L.; Gómez, M. Influence of marine hydrocolloids on extruded and native wheat flour pastes and gels. Food Hydrocolloids. 2015, 43, 172-179.

[23] Toyokawa, H.; Rubenthaler, G.L.; Powers, J.R.; Schanus, E.G. Japanese noodle qualities. I. Flour components. Cereal Chemistry. 1989, 66, 382-386.

[24] Rosell, C.M.; Yokoyama, W.; Shoemaker, C. Rheology of different hydrocolloids-rice starch blends. Effect of successive heating-cooling cycles. Carbohydrate Polymers.2011, 84, 373-382

[25] AACC. Method 61-02.01 (pasting properties), In Approved methods of the American Association of Cereal Chemists, (11th ed.). St. 506 Paul, Minnesota, 2012 
[26] Shin, M.; Gang, D.O.; Song, J.Y. Effects of protein and transglutaminase on the preparation of gluten-free rice bread. Food Science and Biotechnology. 2010, 19, 951-956.

[27] Fraser, R.D.B.; Macrae, T.P.; Suzuki, E. Chain conformation in the collagen molecule. Journal of Molecular Biology.1979, 129, 463-481.

[28] Bella, J.; Brodsky, B.; Berman, H.M. Hydration structure of a collagen peptide. Structure. 1995, 3, 893-906.

[29] Damodaran, S. Amino acids, Peptides and Proteins, In Fennema's Food Chemistry (4th edition; Damodaran, S.; Parkin, K.L.; Kilk, L.; Fennema, O.R., Eds,; Boca Ratón: CRC PressTylor \& Francis, 2008, Chapter 5.

[30] Kuntz, I. D.; Kauzmann, W. Hydration of proteins and polypeptides. Advances in Protein Chemistry. 1974, 28, 239-345.

[31] Martínez, M.M.; Rosell, C.M.; Gómez, M. Modification of wheat flour functionality and digestibility through different extrusion conditions. Journal of Food Engineering. 2014, 143, 7479.

[32] Hagenimana, A.; Ding, X.; Fang, T. Evaluation of rice flour modified by extrusion cooking. Journal of Cereal Science. 2006, 43, 38-46.

[33] Eliasson, A.C. Differential scanning calorimetry studies on wheat starch-gluten mixtures: I. Effect of gluten on the gelatinization of wheat starch. Journal of Cereal Science. 1983, 1, 199205.

[34] Noisuwan, A.; Hemar, Y.; Wilkinson, B.; Bronlund, J.E. Adsorption of milk proteins onto rice starch granules. Carbohydrate Polymers. 2011, 84, 247-254.

[35] Ferreira, M.; Hofer, C.; Raemy, A. A calorimetric study of egg white proteins. Journal of Thermal Analysis and Calorimetry. 1997, 48, 683-690.

[36] Desert, C.; Guerin-Dubiard, C.; Nau, F.; Jan, G.; Val, F.; Mallard, J. Comparison of different electrophoretic separations of hen egg white proteins. Journal of Agricultural and Food Chemistry. 2001, 49, 4553-4561.

[37] Mine, Y.; Noutomi, T.; \& Haga, N. Thermally induced changes in egg white proteins. Journal of Agricultural and Food Chemistry. 1990, 38, 2122-2125

[38] Martínez, M.M.; Calviño, A.; Rosell, C.M.; Gómez, M. Effect of different extrusion treatments and particle size distribution on the physicochemical properties of rice flour. Food and Bioprocess Technology. 2014, 7, 2657-2665. 
[39] Donovan, J.W.; Mapes, C.J. Multiple phase transitions of starches and nageli amylopectin. Starch/Stärke. 1980, 32, 190-193.

[40] LeCorre, D.; Bras, J.; Dufresne, A. Influence of native starch's properties on starch nanocrystals thermal properties. Carbohydrate Polymers. 2012, 87, 658-666.

[41] Colombo, A.; Leon, A.E.; Ribotta, P.D. Rheological and calorimetric properties of corn-, wheat-, and cassava- starches and soybean protein concentrate composites. Starch-Starke. 2011, 63, 83-95.

[42] Li, J.Y.; Yeh, A.I.; Fan, K.L. Gelation characteristics and morphology of corn starch/soy protein concentrate composites during heating. Journal of Food Engineering .2007, 78, 12401247.

[43] Heyman, B.; Depypere, F.; Delbaere, C.; Dewettinck, K. Effects of non-starch hydrocolloids on the physicochemical properties and stability of a commercial béchamel sauce. Journal of Food Engineering. 2010, 99, 115-120.

[44] Rosalina, I.; Bhattacharya, M. Dynamic rheological measurements and analysis of starch gels. Carbohydrate Polymers. 2002, 48, 191-202 
Table 1. Hydration properties of native maize flour (NMF), extruded maize flour (EMF) and mixtures.

\begin{tabular}{lccccc} 
Flour & Protein & $\begin{array}{c}\% \text { of } \\
\text { protein }\end{array}$ & $\begin{array}{c}\text { WHC (g water/g } \\
\text { solid) }\end{array}$ & $\begin{array}{c}\text { WBC (ml water/g } \\
\text { solid) }\end{array}$ & $\begin{array}{c}\text { SV (g water/g } \\
\text { solid) }\end{array}$ \\
\hline NMF & - & - & $2.27 \mathrm{~cd}$ & $1.72 \mathrm{c}$ & $0.30 \mathrm{ab}$ \\
EFM & - & - & 7.861 & $4.70 \mathrm{i}$ & $0.83 \mathrm{i}$ \\
\hline NMF & Egg & $25 \%$ & $1.95 \mathrm{bc}$ & $1.08 \mathrm{~b}$ & $0.36 \mathrm{bc}$ \\
NMF & Collagen & $25 \%$ & $3.69 \mathrm{fg}$ & $3.17 \mathrm{f}$ & $0.52 \mathrm{efg}$ \\
NMF & Milk & $25 \%$ & $2.72 \mathrm{e}$ & $1.88 \mathrm{~cd}$ & $0.46 \mathrm{def}$ \\
NMF & Whey & $25 \%$ & $1.85 \mathrm{~b}$ & $1.07 \mathrm{~b}$ & $0.25 \mathrm{a}$ \\
NMF & Egg & $50 \%$ & $1.32 \mathrm{a}$ & $0.51 \mathrm{a}$ & $0.24 \mathrm{a}$ \\
NMF & Collagen & $50 \%$ & $3.93 \mathrm{gh}$ & $5.74 \mathrm{k}$ & $0.60 \mathrm{gh}$ \\
NMF & Milk & $50 \%$ & $2.79 \mathrm{e}$ & $2.58 \mathrm{e}$ & $0.50 \mathrm{def}$ \\
NMF & Whey & $50 \%$ & $1.10 \mathrm{a}$ & $0.42 \mathrm{a}$ & $0.22 \mathrm{a}$ \\
\hline EMF & Egg & $25 \%$ & $4.89 \mathrm{i}$ & $3.51 \mathrm{~g}$ & $0.54 \mathrm{fg}$ \\
EMF & Collagen & $25 \%$ & $8.70 \mathrm{~m}$ & $5.38 \mathrm{j}$ & $1.06 \mathrm{j}$ \\
EMF & Milk & $25 \%$ & $5.91 \mathrm{k}$ & $4.73 \mathrm{i}$ & $0.69 \mathrm{~h}$ \\
EMF & Whey & $25 \%$ & $4.23 \mathrm{~h}$ & $3.51 \mathrm{~g}$ & $0.47 \mathrm{def}$ \\
EMF & Egg & $50 \%$ & $2.59 \mathrm{de}$ & $2.03 \mathrm{~d}$ & $0.42 \mathrm{~cd}$ \\
EMF & Collagen & $50 \%$ & $9.12 \mathrm{~m}$ & 6.621 & $1.21 \mathrm{k}$ \\
EMF & Milk & $50 \%$ & $5.42 \mathrm{j}$ & $4.30 \mathrm{~h}$ & $0.68 \mathrm{~h}$ \\
EMF & Whey & $50 \%$ & $3.36 \mathrm{f}$ & $1.99 \mathrm{~cd}$ & $0.44 \mathrm{cde}$ \\
\hline
\end{tabular}

Water holding capacity (WHC). Water binding capacity (WBC). Swelling volume (SV). Values followed by different letters indicate significant differences. 
Table 2. Gelling properties of native maize flour (NMF), extruded maize flour (EMF) and mixtures.

\begin{tabular}{lccccc} 
Flour & Protein & $\%$ of protein & WAI $(\mathrm{g} / \mathrm{g})$ & WSI $(\mathrm{g} / 100 \mathrm{~g})$ & $\mathrm{SP}(\mathrm{g} / \mathrm{g})$ \\
\hline NMF & - & - & $10.02 \mathrm{cde}$ & $1.59 \mathrm{ab}$ & $10.18 \mathrm{ab}$ \\
EFM & - & - & $9.58 \mathrm{bcde}$ & $6.33 \mathrm{bc}$ & $10.22 \mathrm{ab}$ \\
\hline NMF & Egg & $25 \%$ & $8.27 \mathrm{abcde}$ & $16.34 \mathrm{de}$ & $9.89 \mathrm{ab}$ \\
NMF & Collagen & $25 \%$ & $10.44 \mathrm{de}$ & $6.93 \mathrm{bc}$ & $11.22 \mathrm{ab}$ \\
NMF & Milk & $25 \%$ & $9.26 \mathrm{bcde}$ & $6.82 \mathrm{bc}$ & $9.94 \mathrm{ab}$ \\
NMF & Whey & $25 \%$ & $9.67 \mathrm{bcde}$ & $9.80 \mathrm{~cd}$ & $10.72 \mathrm{ab}$ \\
NMF & Egg & $50 \%$ & $6.71 \mathrm{abc}$ & $32.61 \mathrm{~g}$ & $9.95 \mathrm{ab}$ \\
NMF & Collagen & $50 \%$ & $20.35 \mathrm{f}$ & $-0.13 \mathrm{ab}$ & $20.33 \mathrm{c}$ \\
NMF & Milk & $50 \%$ & $8.15 \mathrm{abcde}$ & $12.05 \mathrm{~cd}$ & $9.28 \mathrm{a}$ \\
NMF & Whey & $50 \%$ & $7.62 \mathrm{abcd}$ & $21.88 \mathrm{ef}$ & $9.76 \mathrm{ab}$ \\
\hline EMF & Egg & $25 \%$ & $7.25 \mathrm{abcd}$ & $29.35 \mathrm{~g}$ & $10.26 \mathrm{ab}$ \\
EMF & Collagen & $25 \%$ & $11.69 \mathrm{e}$ & $12.68 \mathrm{~cd}$ & $13.38 \mathrm{ab}$ \\
EMF & Milk & $25 \%$ & $7.74 \mathrm{abcd}$ & $32.50 \mathrm{~g}$ & $11.64 \mathrm{ab}$ \\
EMF & Whey & $25 \%$ & $6.35 \mathrm{ab}$ & $28.37 \mathrm{fg}$ & $8.84 \mathrm{a}$ \\
EMF & Egg & $50 \%$ & $5.42 \mathrm{a}$ & $46.53 \mathrm{~h}$ & $10.13 \mathrm{ab}$ \\
EMF & Collagen & $50 \%$ & $20.30 \mathrm{f}$ & $-1.49 \mathrm{a}$ & $20.00 \mathrm{c}$ \\
EMF & Milk & $50 \%$ & $7.35 \mathrm{abcd}$ & $21.10 \mathrm{e}$ & $9.32 \mathrm{a}$ \\
EMF & Whey & $50 \%$ & $10.00 \mathrm{cde}$ & $34.29 \mathrm{~g}$ & $15.86 \mathrm{bc}$ \\
\hline
\end{tabular}

Water absorption index (WAI). Water solubility index (WSI). Swelling power (SP). Values followed by different letters indicate significant differences.

Table 3. Thermal properties of native maize flour (NMF) and mixtures with proteins.

\begin{tabular}{lccclll} 
Flour & Protein & $\%$ of protein & Entalpy $(\mathrm{g} / \mathrm{J})$ & $\mathrm{To}\left({ }^{\circ} \mathrm{C}\right)$ & $\mathrm{Tp}\left({ }^{\circ} \mathrm{C}\right)$ & $\mathrm{Tc}\left({ }^{\circ} \mathrm{C}\right)$ \\
\hline NMF & - & - & $5.37 \mathrm{~d}$ & $66.34 \mathrm{a}$ & $72.59 \mathrm{a}$ & $83.47 \mathrm{a}$ \\
\hline NMF & Egg & $25 \%$ & $5.22 \mathrm{~d}$ & $69.91 \mathrm{c}$ & $77.27 \mathrm{e}$ & $88.94 \mathrm{~cd}$ \\
NMF & Collagen & $25 \%$ & $4.13 \mathrm{c}$ & $67.74 \mathrm{bc}$ & $74.10 \mathrm{~b}$ & $86.37 \mathrm{~b}$ \\
NMF & Milk & $25 \%$ & $5.43 \mathrm{~d}$ & $67.85 \mathrm{bc}$ & $73.78 \mathrm{ab}$ & $86.69 \mathrm{~b}$ \\
NMF & Whey & $25 \%$ & $5.11 \mathrm{~d}$ & $67.66 \mathrm{~b}$ & $75.96 \mathrm{~cd}$ & $85.90 \mathrm{~b}$ \\
NMF & Egg & $50 \%$ & $4.60 \mathrm{c}$ & $72.30 \mathrm{e}$ & $81.44 \mathrm{f}$ & $90.25 \mathrm{~d}$ \\
NMF & Collagen & $50 \%$ & $2.04 \mathrm{a}$ & $68.86 \mathrm{~cd}$ & $77.00 \mathrm{de}$ & $87.55 \mathrm{bc}$ \\
NMF & Milk & $50 \%$ & $2.66 \mathrm{~b}$ & $69.04 \mathrm{~d}$ & $75.58 \mathrm{c}$ & $82.82 \mathrm{~b}$ \\
NMF & Whey & $50 \%$ & $4.26 \mathrm{c}$ & $71.11 \mathrm{e}$ & $77.39 \mathrm{e}$ & $86.99 \mathrm{bc}$ \\
\hline
\end{tabular}

Onset temperature (To). Maximum peak temperature (Tp). Final temperature (Tf). Values followed by different letters indicate significant differences. 
Table 4. Textural properties of native maize flour (NMF), extruded maize flour (EMF) and mixtures with proteins.

\begin{tabular}{lcccc} 
Flour & Protein & $\%$ of protein & Hardness $(\mathrm{N})$ & Slope $\left(\mathrm{Kg} / \mathrm{s}^{2}\right)$ \\
\hline NMF & - & - & $4.62 \mathrm{f}$ & $997 \mathrm{~h}$ \\
EMF & - & - & $4.40 \mathrm{f}$ & $631 \mathrm{f}$ \\
\hline NMF & Egg & $25 \%$ & $3.09 \mathrm{de}$ & $790 \mathrm{fg}$ \\
NMF & Collagen & $25 \%$ & $11.52 \mathrm{~g}$ & $2850 \mathrm{i}$ \\
NMF & Milk & $25 \%$ & $1.21 \mathrm{abc}$ & $259 \mathrm{bcde}$ \\
NMF & Whey & $25 \%$ & $1.32 \mathrm{abc}$ & $334 \mathrm{cde}$ \\
NMF & Egg & $50 \%$ & $2.05 \mathrm{~cd}$ & $205 \mathrm{abcd}$ \\
NMF & Collagen & $50 \%$ & $42.41 \mathrm{i}$ & $4903 \mathrm{k}$ \\
NMF & Milk & $50 \%$ & $0.38 \mathrm{a}$ & $52 \mathrm{a}$ \\
NMF & Whey & $50 \%$ & $4.13 \mathrm{ef}$ & $413 \mathrm{e}$ \\
\hline EMF & Egg & $25 \%$ & $1.95 \mathrm{bc}$ & $342 \mathrm{de}$ \\
EMF & Collagen & $25 \%$ & $4.89 \mathrm{f}$ & $908 \mathrm{gh}$ \\
EMF & Milk & $25 \%$ & $0.97 \mathrm{ab}$ & $156 \mathrm{abc}$ \\
EMF & Whey & $25 \%$ & $1.09 \mathrm{abc}$ & $167 \mathrm{abcd}$ \\
EMF & Egg & $50 \%$ & $1.25 \mathrm{abc}$ & $227 \mathrm{abcd}$ \\
EMF & Collagen & $50 \%$ & $31.19 \mathrm{~h}$ & $3183 \mathrm{j}$ \\
EMF & Milk & $50 \%$ & 0.40 & $50 \mathrm{a}$ \\
EMF & Whey & $50 \%$ & $0.472 \mathrm{a}$ & $95 \mathrm{ab}$ \\
\hline
\end{tabular}

Values followed by different letters indicate significant differences. 
Figure 1. RVA curves of flour-protein mixtures of: native flour with $25 \%$ (A) and $50 \%$ (B) protein content, and extruded flour with 25\% (C)and 50\% (D)protein content. Flours (black continuous line). Mixtures with milk proteins (black circles). Mixtures with whey proteins (grey triangles). Mixtures with collagen proteins (discontinuous line). Mixtures with egg proteins (spotted line). Temperature profile (Upper continuous grey line). Different scale of y-axis between curves with native flour and extruded flour should be considered.

A)

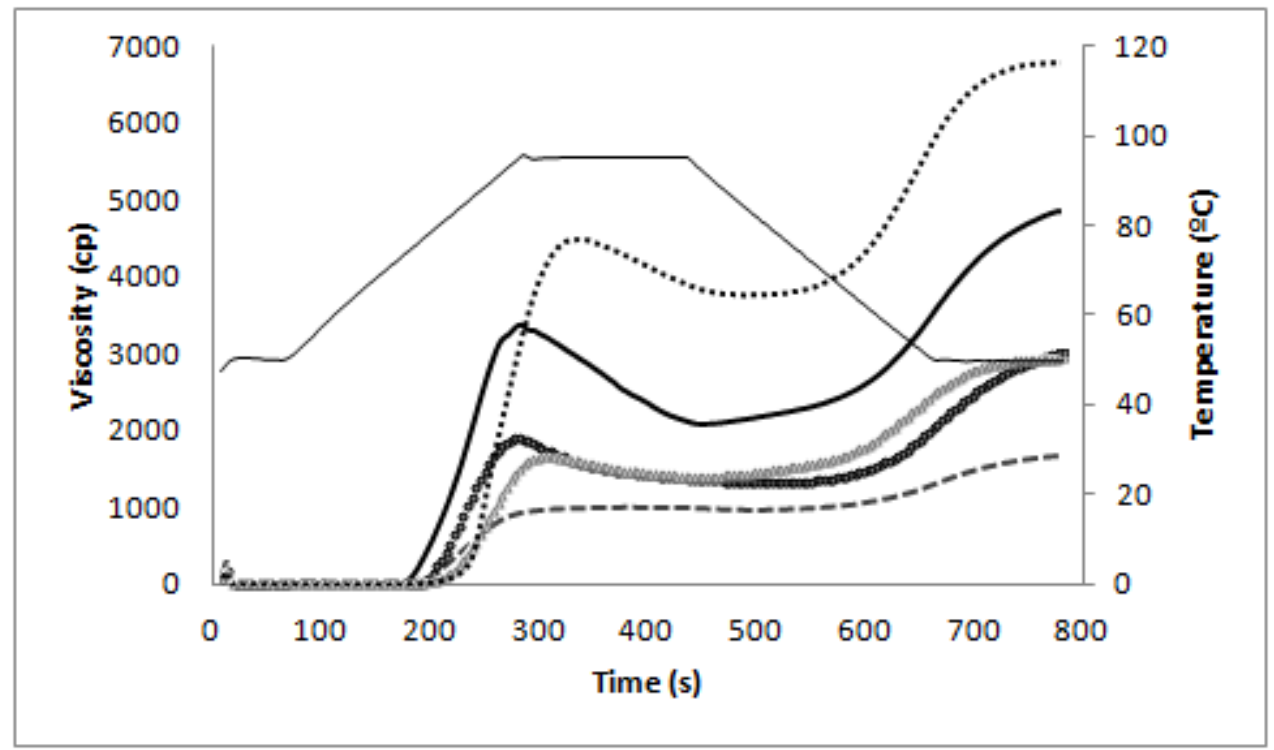

B)

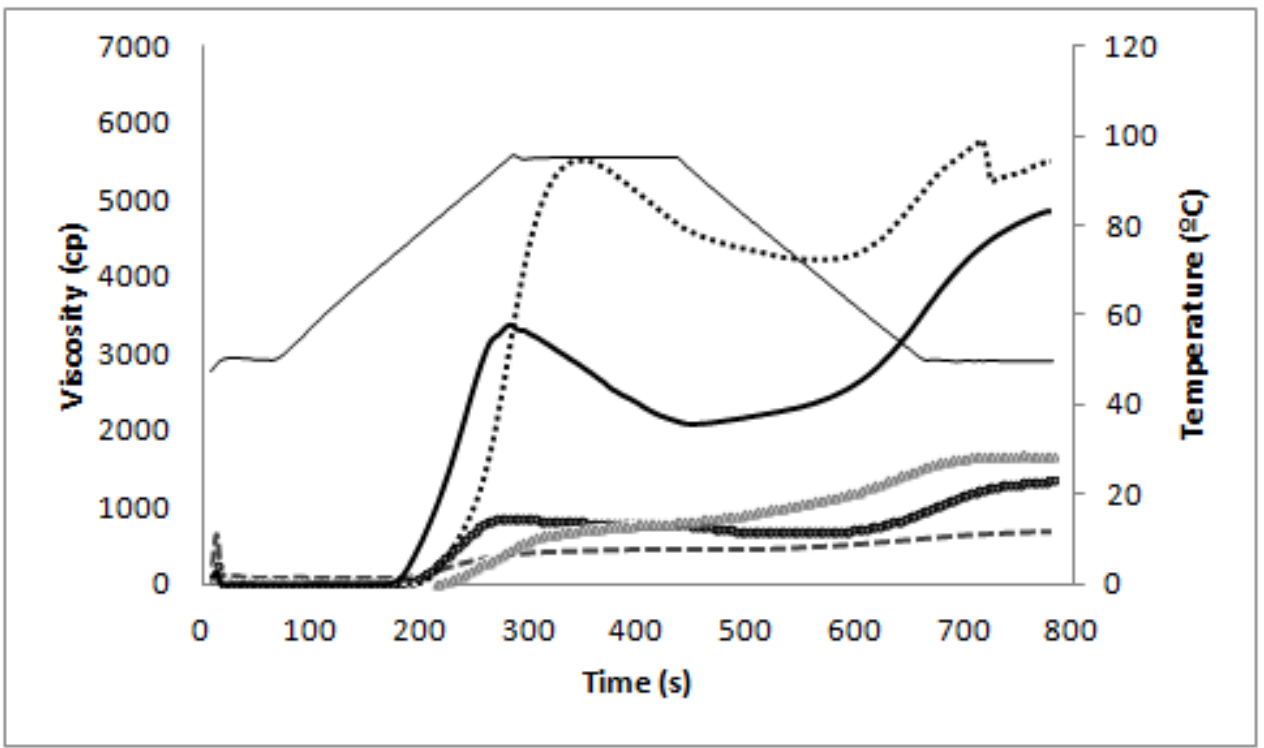


C)

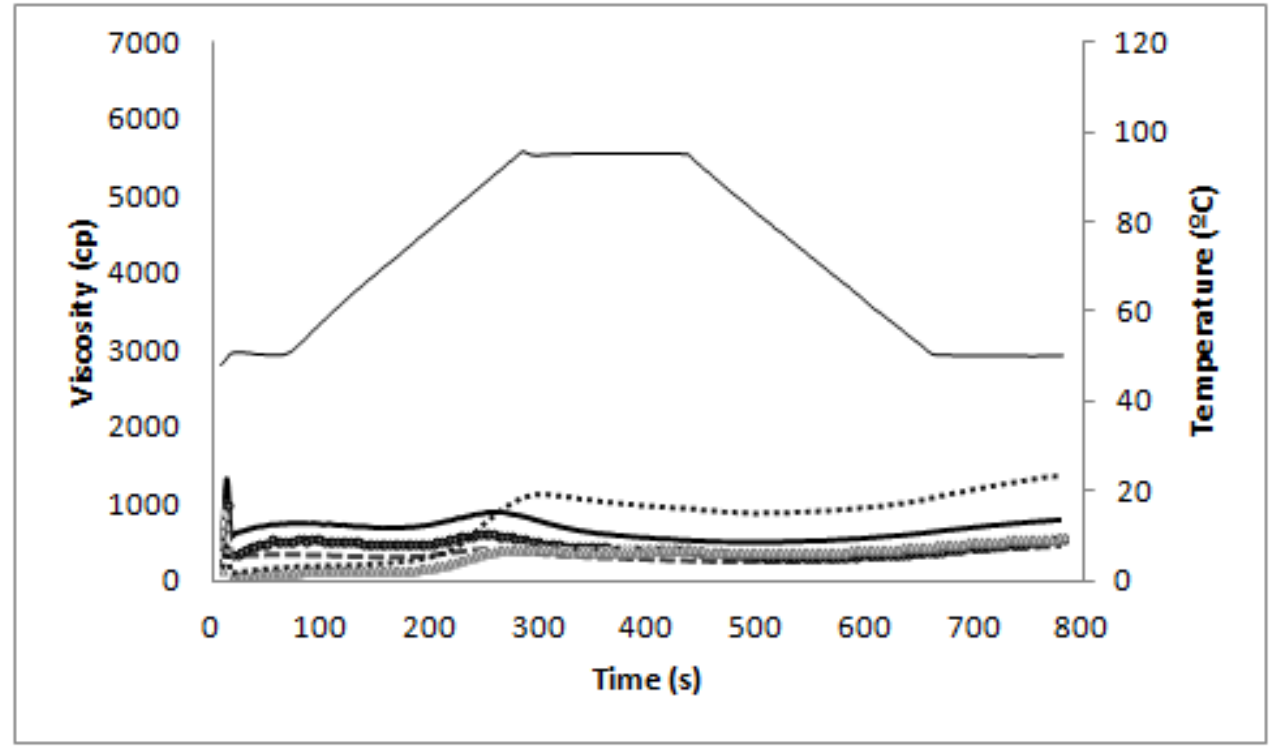

D)

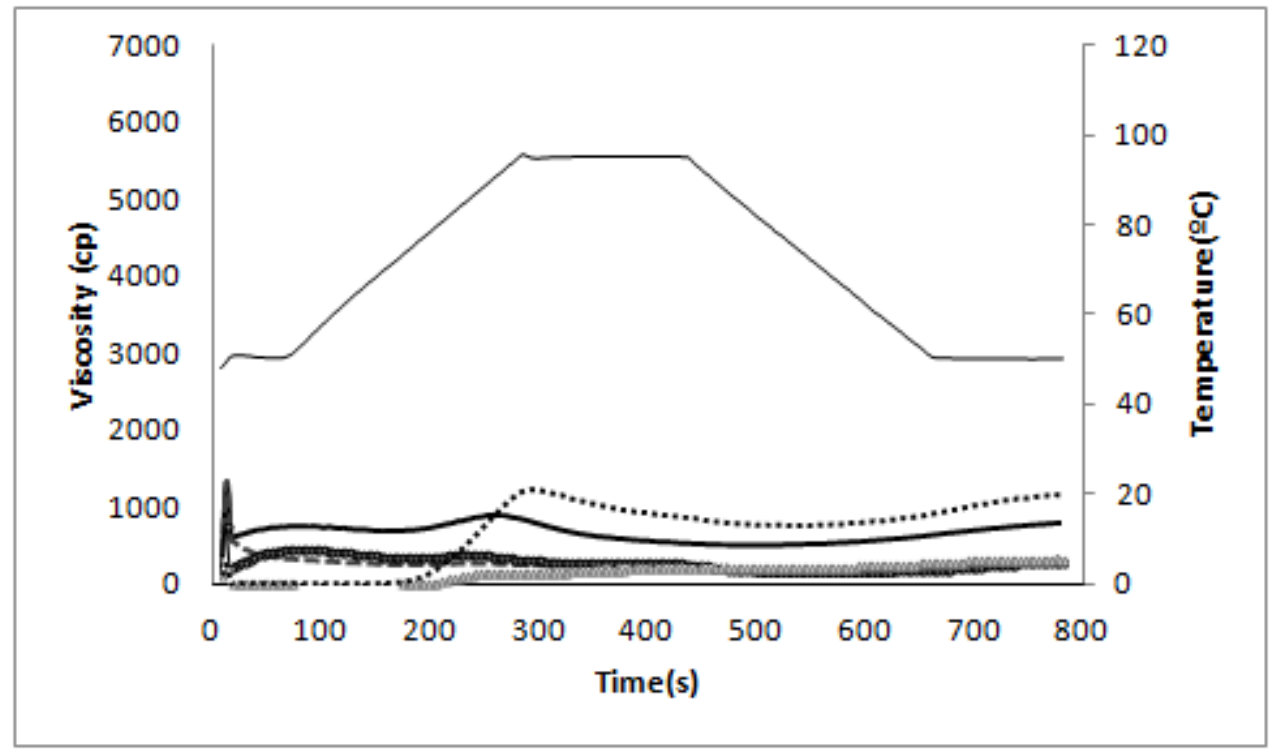


Figure 2. Frequency sweep tests at $30{ }^{\circ} \mathrm{C}$ of flour-protein mixtures of: native flour with $25 \%$ (A) and 50\% (B) protein content, and extruded flour with 25\% (C) and 50\% (D) protein content. Flours (continuous line). Mixtures with milk proteins (circles). Mixtures with whey proteins (grey triangles). Mixtures with collagen proteins. (discontinuous line). Mixtures with egg proteins (spotted line).

A)

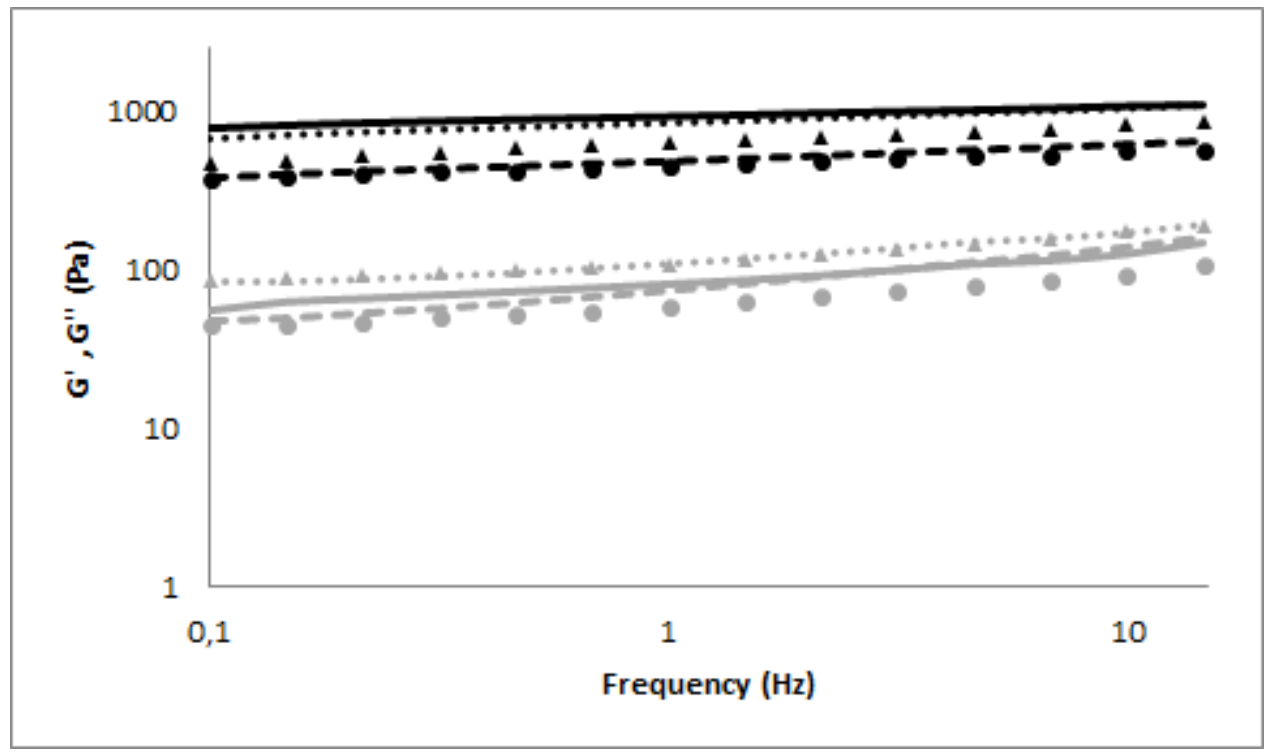

B)

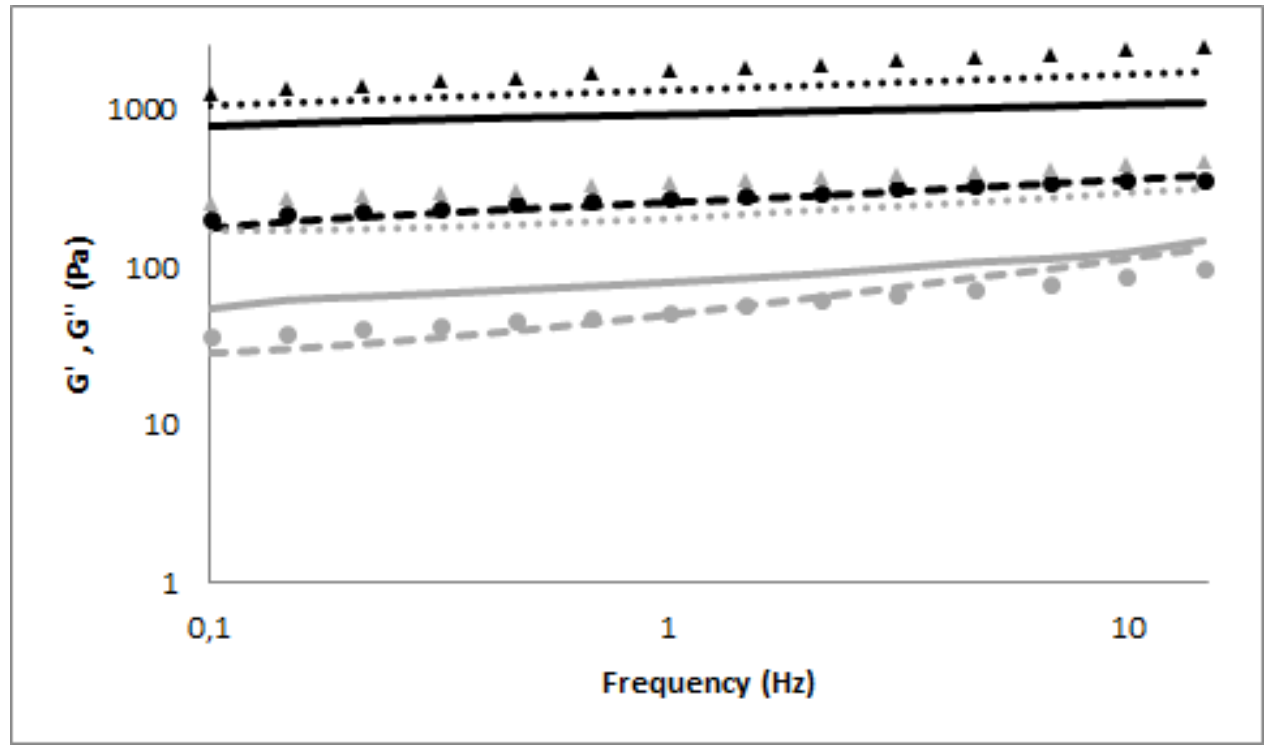


C)

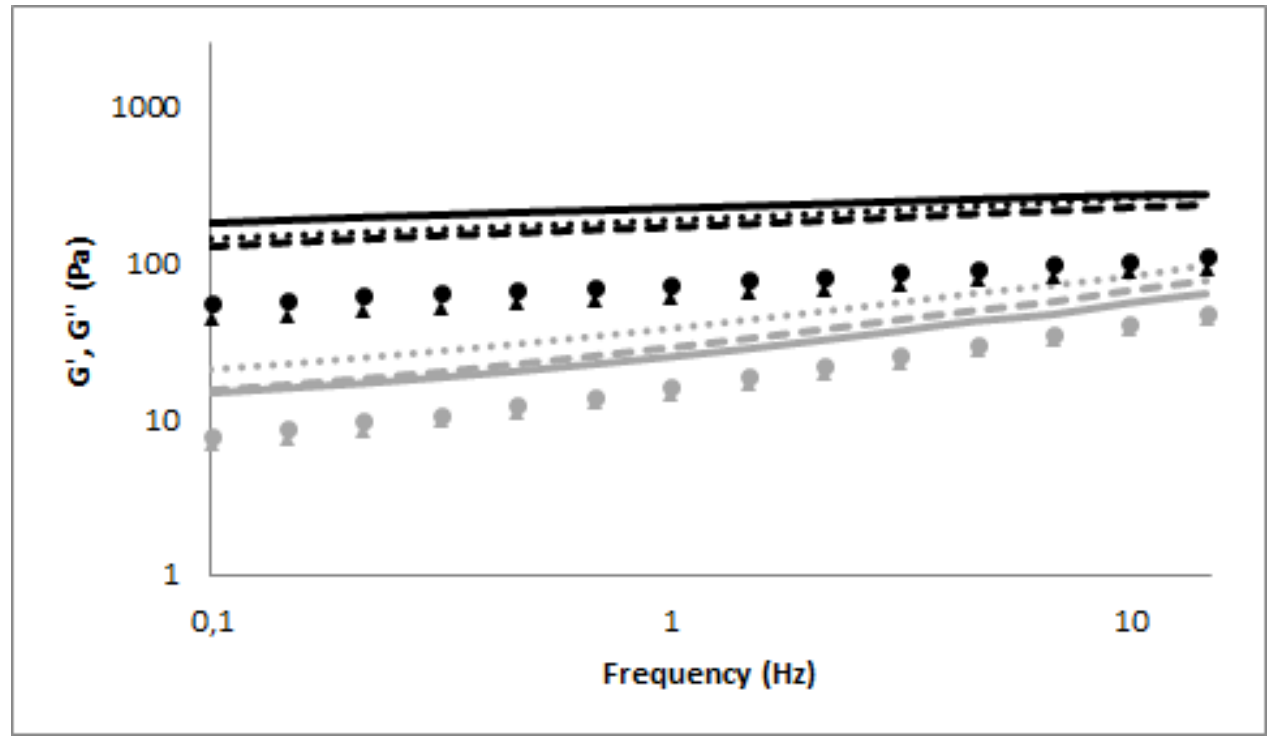

D)

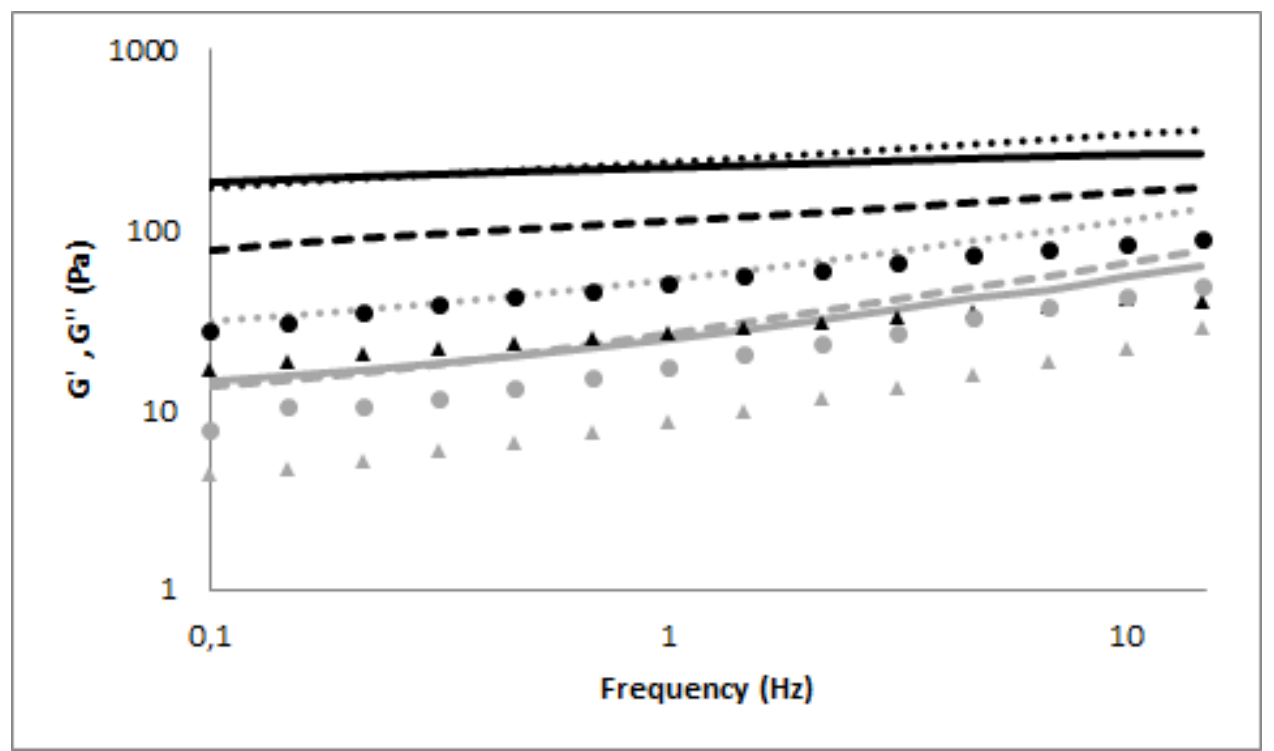


Figure 3. Loss factor as function of frequency of flour-protein mixtures of native flour with 25\%(A) and 50\%(B) protein content, and extruded flour with 25\% (C)and 50\% (D) protein content. Flours (continuous line). Mixtures with milk proteins (circles). Mixtures with whey proteins (grey triangles). Mixtures with collagen proteins. (discontinuous line). Mixtures with egg proteins (spotted line).

A)

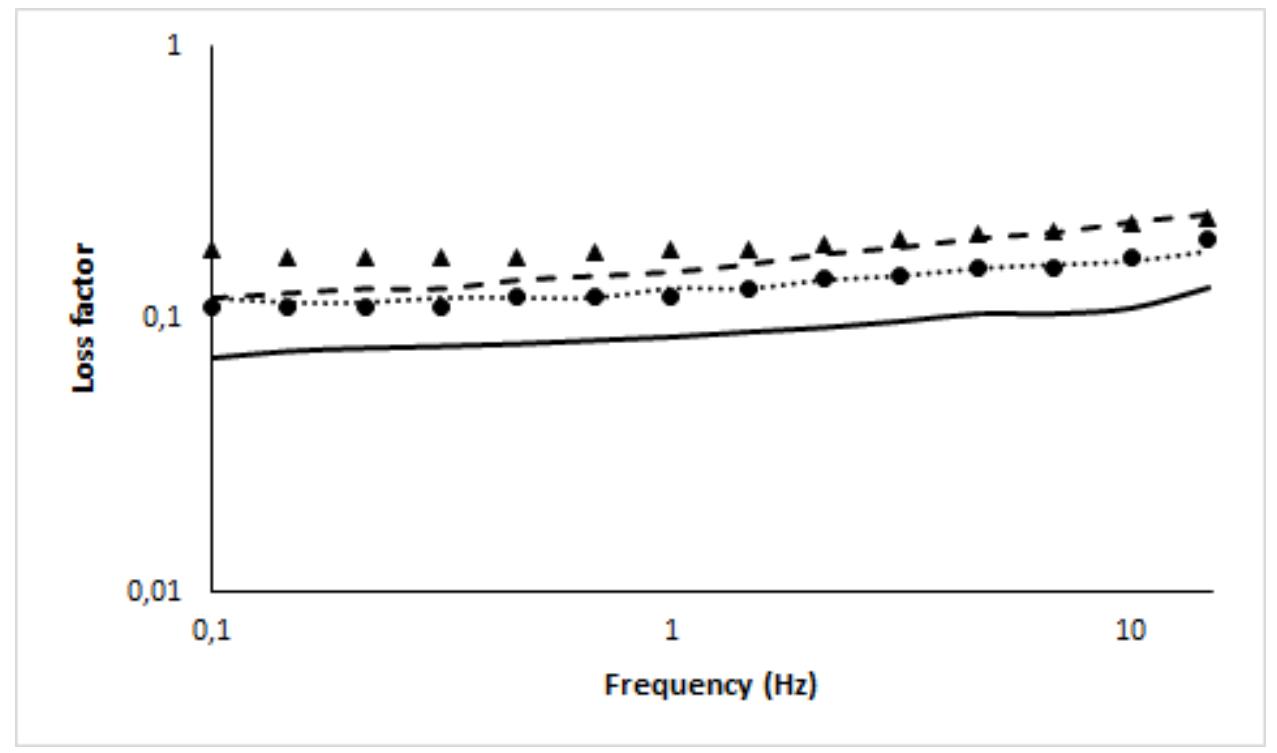

B)

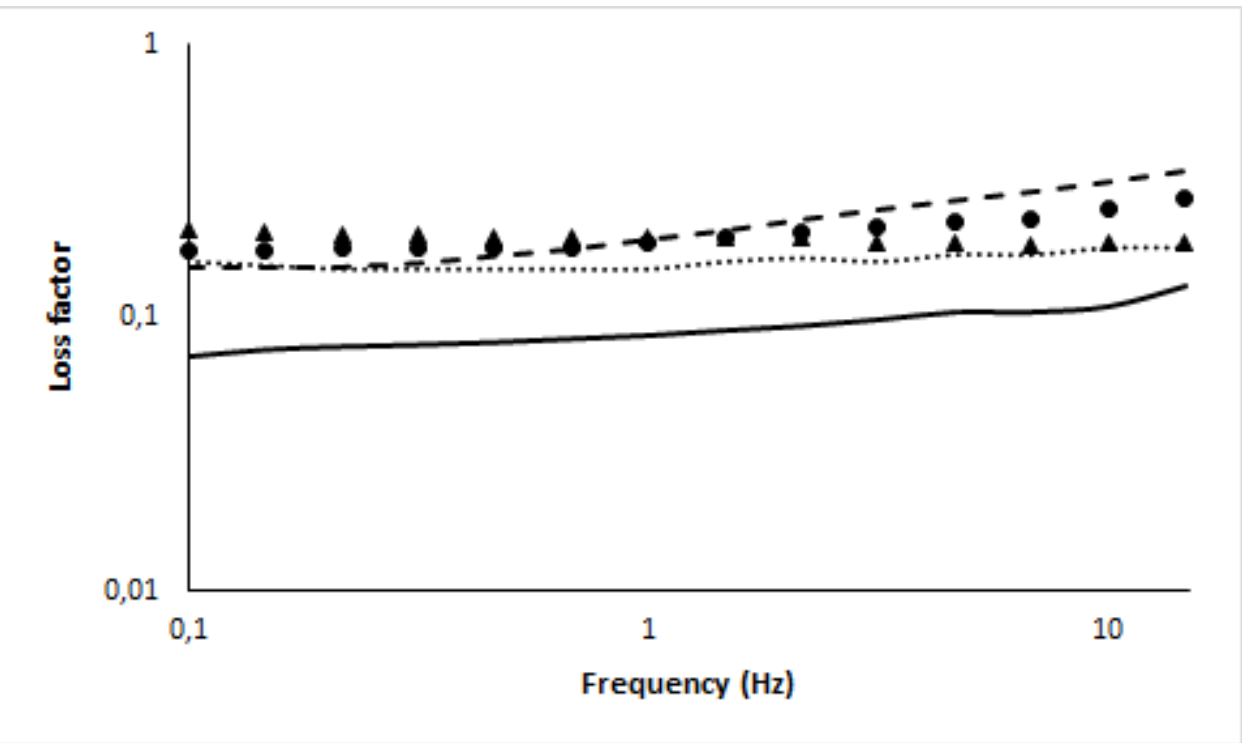


C)

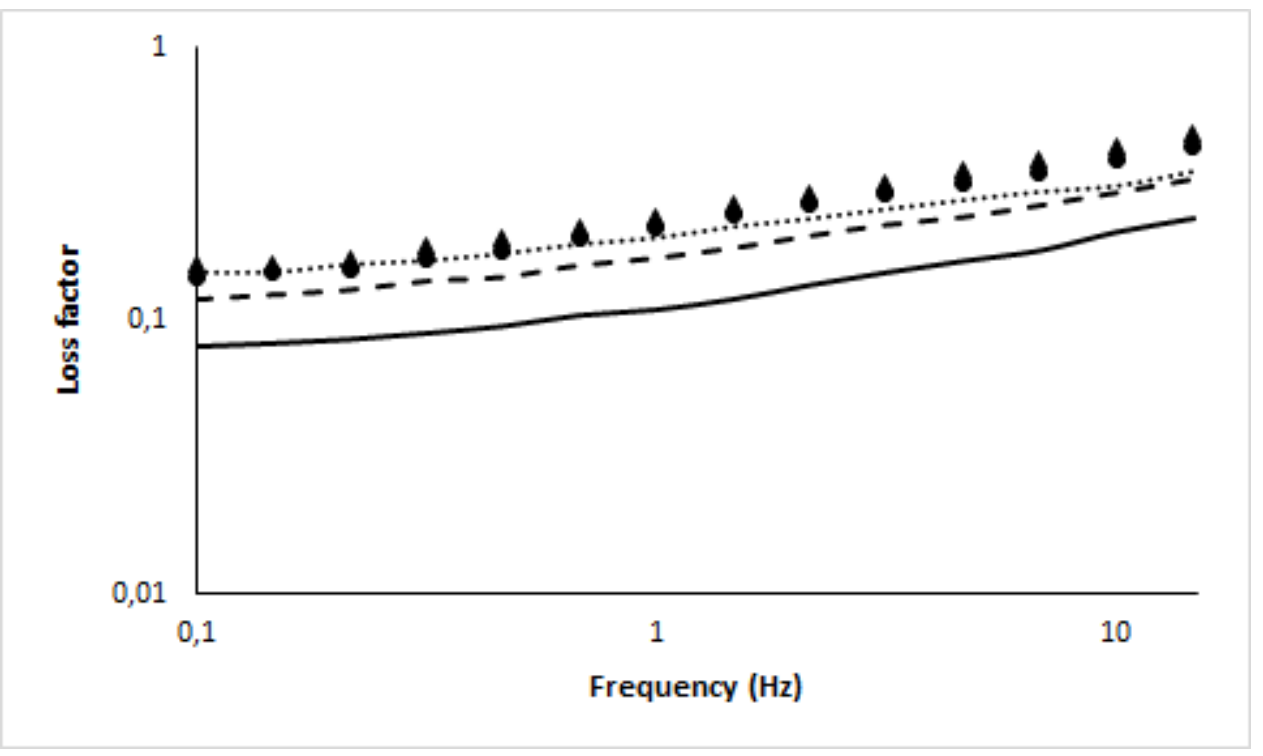

D)

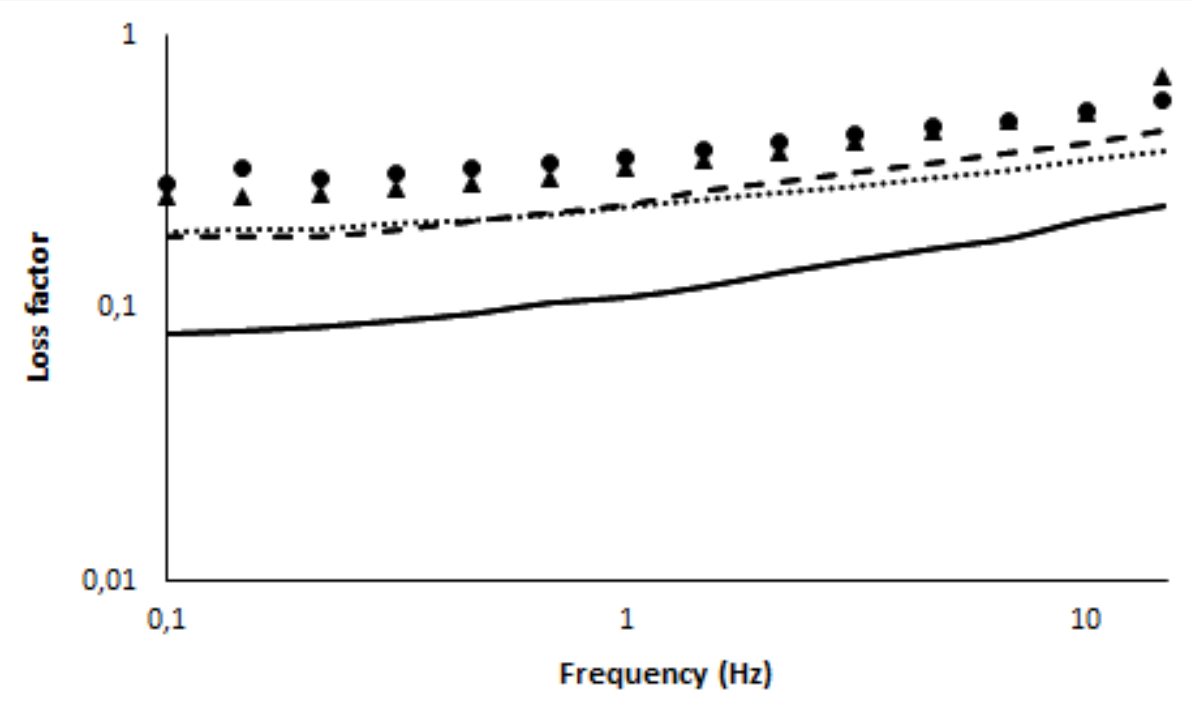

